Article

\title{
Hope in Exile: In Conversation with Ezekiel
}

\author{
Janina M. Hiebel
}

Biblical Department, Yarra Theological Union, University of Divinity, Melbourne VIC 3128, Australia; j.hiebel@ytu.edu.au

Received: 12 July 2019; Accepted: 9 August 2019; Published: 14 August 2019

\begin{abstract}
The question of hope in dark times, though topical, is not new. The Babylonian Exile (597/587-539 BCE) is commonly recognised as perhaps the most profound, yet also most fruitful crisis in biblical (Old Testament) times. It involved the total breakdown of all religious and political structures and institutions that previously had provided meaning and protection, yet it led to significant theological progress, laying the foundations for both Judaism and Christianity. Today the metaphor of exile is sometimes used with reference to the present; however, the connection is usually not further explored. This article examines a biblical exilic voice, the book of Ezekiel, which offers an initial prophetic response to the theological, political and identity crisis of the early Babylonian Exile. While resisting both optimism and despair, Ezekiel arrives at an original, if peculiar, imagination of hope, founded solely on theological conviction. The article outlines this process by discussing select texts of the book as examples, and opens it up to conversation with the present. The logic of Ezekiel's theocentric hope is bound to ultimately remain foreign to modern thinking. However, while it cannot be directly transferred into our times, the article aims to demonstrate that theological reflection on Ezekiel still yields valuable and transferable impulses for thought.
\end{abstract}

Keywords: hope; book of Ezekiel; Babylonian Exile; Ezek 37:1-14; Ezek 13:1-16; Ezek 20:1-44; theocentricity; dark times

\section{Introduction}

“Dark times [ ... ] are not only not new, they are no rarity in history" (Arendt 1973, p. 9). The phrase "dark times" ("finstere Zeiten") is taken from Brecht's poem "An die Nachgeborenen" (Arendt 1973, p. 7), which was written between 1934 and 1938, during Brecht's own exile. For both Brecht and Arendt "dark times are not merely times of horror but times of confusion in which theory no longer helps us to act" and where "traditional forms of explanation no longer explain anything" (Luban 1983, p. 218), as events overturn theory and even moral standards (Cornell 2010, p. 221).

This definition applies to the 20th and 21st centuries $\mathrm{CE}$ as well as to many moments of the biblical era. The Babylonian Exile (597/587-539 BCE) in particular is commonly recognised as perhaps the most profound, yet also the most fruitful crisis of Old Testament times. Today the metaphor of exile is sometimes used in reference to the present day by Christian public speakers and writers ${ }^{1}$; however, the connection is usually not further explored. This article, written from the perspective of a Christian biblical scholar, examines a biblical exilic voice, the book of Ezekiel, which offers an initial prophetic response to the theological, political and identity crisis of the early Babylonian Exile. The intention is to engage this voice from a very different historical and cultural setting in a conversation with present-day thinkers, by offering in outline some of Ezekiel's key theological ideas on hope, and by noting-from

1 To list just two examples from the Australian Catholic scene, the bishop of Parramatta, Vincent Long, uses this metaphor frequently in his addresses. It is also employed in the recent book by journalist Greg Sheridan, God is Good for You. From America, also Rod Dreher's popular The Benedict Option speaks of the present/future as exile. 
the perspective of an amateur in this field-similarities to Arendt's Men in Dark Times or to the present more in general. It is intended as an invitation to dialogue between antiquity and (post)modernity. The assumption behind this is that, as a key witness to the greatest successfully overcome crisis in Old Testament times, the book of Ezekiel may be able to offer helpful insights for the present, despite the differences in historical circumstances and cultural values.

For the purposes of this article, the Masoretic Text of the book of Ezekiel will provide the main reference point. While a process of redaction is assumed for the book, no matters related to this will be discussed here. Different from a growing tendency in German scholarship, a 6th-century early exilic setting will be assumed for the texts discussed, with a significant portion of these texts attributed to the original prophetic figure we call Ezekiel who was active in Babylonia in the years prior to and after the fall of Jerusalem in 587 BCE. For a summary of arguments for a 6th-century exilic setting of the book of Ezekiel, see e.g., Joyce (2009, pp. 3-6) and Smith-Christopher (2002, pp. 75-104).

After presenting the Babylonian Exile as a particular instance of dark times, a discussion of selected relevant texts from the book of Ezekiel will provide the basis for outlining the kind of hope present therein, as a hope not centred on historical merits and familiar religious traditions but unexpectedly emerging from a transcendent source after all contingent certainties have ceased.

\section{Exile and Dark Times}

The beginning of the Babylonian Exile can be regarded as a "dark time" in the sense in which Hannah Arendt uses this term. At the start of the 6th century BCE, the people of Judah-the remaining political and religious entity representing the heirs of the covenants with Abraham and Moses-found themselves not only in a world in crisis but they practically experienced the end of the world as they knew it.

Less than 40 years earlier, a generation after the demise of the larger and stronger Kingdom of Israel at the hands of the Assyrian Empire, the reforms and ambitious expansion politics of King Josiah had boosted Judean national identity and hopes, while the until-then international superpower of Assyria was rapidly collapsing, finally releasing its grip on the Southern Levant. Judah was free, it was growing, and Josiah's cultic reforms meant that it was implementing laws that came from God, which would surely secure blessings and prosperity (see Deut 28:1-14). But then Josiah died a sudden and violent death, the political landscape around Judah changed dramatically, with the Babylonians establishing themselves as the heirs of the Assyrian Empire, and Josiah's successors made a series of unwise political choices.

In 597 BCE, only 25 years after Josiah's reforms, his grandson Jehoiachin was forced to surrender Jerusalem to the Babylonian king Nebuchadnezzar. Jehoiachin was taken prisoner and exiled to Babylon, along with a large number of elite Judeans. The Babylonians chose Jehoiachin's uncle Zedekiah as the new vassal king in Jerusalem. Yet Zedekiah was easily won over by those in Jerusalem who wanted to assert Judah's independence, shake off the yoke of the Babylonian taxes, and plot rebellion. As a result, Jerusalem-the supposedly unconquerable city-was conquered a second time in $587 \mathrm{BCE}$, after a long and cruel siege; this time the city and the temple were burnt and largely destroyed. There were executions and more deportations, and this time no new king was installed; instead Judah was reduced to the status of a province in the Babylonian Empire (2 Kings 25:1-21) (Albertz 2003).

While the destructions in Judah were substantial (Faust 2012), even worse was that the events of 597 and especially 587 overturned the theoretical and theological premises on which Judah was founded. On a socio-political level, the collapse of the political and religious institutions was significant. King and priests, political power, and state religion were meant to offer order and safety and to secure and mediate divine blessing and protection. Instead, they had failed to protect the people of Judah. It was the decisions of these leaders which were directly or indirectly to blame for the catastrophe, and now they were disintegrating powerlessly before the Babylonian forces. On a religious-theological level, the events displayed the failure of the divine promises, even of the covenant itself. Israel's God 
YHWH had promised the land to Abraham's descendants (Gen 12:7; 13:14-17; 15:18; 17:8); yet the land had been conquered and many Judeans were deported. YHWH had promised the continuity of the Davidic dynasty (2 Sam 7:12-16), yet the king had been dethroned and deported. YHWH had promised his presence in the temple (1 Kings 9:3), and with Josiah's reform the temple in Jerusalem had become the only legitimate place of cultic worship (2 Kings 23). Yet the temple had been defiled and destroyed, and proper worship was made impossible. None of the institutions usually supposed to provide protection, order, and meaning were left intact (Block 2014a, pp. 26-27). The traditional theories or theologies by which events were interpreted and explained until then proved inadequate to deal with the destructive evidence of the events of the beginning Babylonian Exile. For an overview of the history and socio-religious impact of these events, see e.g., (Smith 1989) and (Albertz 2003) and the literature cited in the recent article by (Delorme 2019).

Those deported to Babylonia were faced with the challenges of losing their privileged status, much of their social network, and their role in society. Their situation has been described in terms of a "social death" (Mein 2001, p. 70). The questions of "Who are we?" and "Where is God in all of this?" were burning questions for them, as their personal and collective identity was under threat. The book of Ezekiel is situated at the crossroads where the old socio-religious paradigm is breaking apart and a new one is yet to be found.

Precisely this makes Ezekiel such an interesting biblical book for our own confusing times in Western societies such as Australia or Western Europe. As mentioned above, "exile" is used not unfrequently in Church contexts as a metaphor to describe our times. Certainly, what is in view is not war, invading armies, or forced deportation. The analogy of exile works on a different level. Significant connections are a general disillusionment, liquefaction of structures and of identity, and the erosion of thought models that used to provide meaning, certainty, and a sense of belonging. For Christians, the transition from a centuries-old majority position to being a minority in an ever-more secularised society (see (Sheridan 2018, pp. 1-32) for a popularising but extensive overview of relevant statistics), as well as the shock of the unfolding abuse scandals in recent times lead to the perception of "being in exile," even without ever leaving one's home. These factors demonstrate the urgent need for a new narrative, for rediscovering identity, and for finding solid foundations for hope (Volf 2012).

In a nutshell, while our external circumstances are quite different from those of the deported Judean elite, for us as for them our future depends on how we meet the challenges of living through dark and confusing times.

\section{What Ezekiel Brings to the Conversation: Hope in Ezekiel}

This article now turns to examine a biblical exilic voice, the book of Ezekiel, which offers an initial prophetic response to the crisis. To appreciate this response "it is important to remember that Ezekiel is not a leisured work of systematic theology but rather an example of crisis literature written in an extreme situation" (Joyce 2009, p. 18). The narrative provided by this prophetic book is not one of comfort; its merciless accusations and its violent imagery do not make it an easy scroll to swallow (Ezek 2:8-3:3). While much of Ezekiel's language, imagery, and reasoning will appear foreign to modern readers, his narrative would have been clearly intelligible to his contemporaries-even though presumably it would have been hard to accept. The exile, according to this narrative, is both inevitable and deserved; it is portrayed as God's judgement for the constant and complete failure of God's people. ${ }^{2}$ At the same time, it is not God's last word. While resisting both optimism and despair, Ezekiel offers a coherent narrative that sheds light on his present and arrives at an original, if peculiar, imagination of hope, founded solely on theological conviction.

2 See, however, Block's notion that the exile itself is also a "grace", as the physical distance from Jerusalem protects the Judeans deported in 597 from the siege and conquest 10 years later, as well as from YHWH's wrath (Block 2014b, pp. 57-59). 
In the following, we shall outline the particular shape of Ezekielian hope. Ezekiel does not use the word "hope" (tqvh), except for two occurrences where it appears together with a verb meaning "perished" or "lost" ('bd, 19:5; 37:11). This is telling. It seems therefore adequate to describe the nature of hope in Ezekiel by contrasting it with what hope is not, discussing selected texts from the book. Ezek 13:1-16 builds a stark contrast between true prophetic voices and unfounded optimism. Ezek 20:1-44 denies the possibility of finding such a foundation for hope in historical or contemporary merits that could ensure divine favour. While there are short texts of hope interspersed in the first, judgement-dominated part of the book of Ezekiel (11:14-21; 16:60-63; 17:22-24; 20:40-44), a sustained message of hope emerges only after the fall of Jerusalem when despair has started to take hold of the exiles. Ezek 37:1-14 demonstrates the life-giving power of the sovereign God who can raise even the dead to life. Based on the belief in YHWH's power and faithfulness-rather than on his mercy or compassion-various texts within Ezek 34-48 paint an idealised and utopian picture of the future restoration, which will depend only on divine saving action, with very limited human collaboration. We will first look briefly at each of these texts in turn and then draw some conclusions in view to a dialogue with present times.

\subsection{Hope vs. Blind Optimism (Ezek 13:1-16)}

"[U]ntil the very moment when catastrophe overtook everything and everybody, it was covered up not by realities but the highly efficient talk and double-talk of nearly all official representatives [ ... ]" (Arendt 1973, p. 8; Berkowitz 2010, p. 4). The situation Arendt had in mind when she wrote those lines was of course very different from that of early-6th-century Judah. She does not address unrealistic optimism but euphemistic or distracting words that cover up rather than illumine reality. Propaganda however- "highly efficient talk and double-talk" - was certainly not absent in in the years between 597 and $588 \mathrm{BCE}$, both among the exiles and in Jerusalem. In hindsight the fall of the kingdom of Judah was highly predictable. Yet it seems to have hit the nation as an immense shock, which would have been due to the many voices that had talked reassuringly about God's certain protection and reliable allies-until it was too late.

For the period between the two conquests of Jerusalem, we find evidence of clashes between opposing prophetic messages both in Jerusalem and in exile in the books of Jeremiah and Ezekiel (Jer 23:9-32; 28; Ezek 13). Whether based on the religious tradition that held that Jerusalem, the holy city, was protected by YHWH and thus unconquerable, or based on political alliances with neighbouring states such as Egypt, there was an influential current both in Jerusalem and among the first group of deportees in Babylonia that expected the near end of the Babylonian oppression and viewed the chances of a successful rebellion as highly favourable.

Ezekiel, by contrast, considers the exile as part of God's just judgement of Judah and expects worse to come. In the first 24 chapters of the book, the message is prevalently one of impending and inescapable doom. Because Ezekiel is convinced that the worst is yet to come, he refuses any easy-way-out hope as nothing more than unfounded optimism. He attacks the prophetic anti-Babylonian propaganda as dangerous, not only because of the risks associated with provoking a very powerful enemy but mainly because their talk obfuscates reality and thus does precisely the opposite of what prophetic talk is supposed to be doing.

In this context, Ezek 13:1-16 is a particularly interesting passage. In this oracle, the prophet accuses some of his colleagues to "follow their own spirits" (v. 3), i.e., to speak merely their own ideas, not according to divine inspiration. Several times he emphasises that their words lack any divine basis (vv. 2, 3, 6, 7, 8, 9), explicitly taking issue with them "because they misled my people, saying, 'All is well,' when nothing was well" (v. 10; translation by Greenberg 1983, p. 232). To reinforce the idea of how a false sense of security may in fact exacerbate danger, Ezekiel uses the image of a wall that people have built-presumably for protection—on which these "senseless prophets" (v. 3) eagerly put some kind of plaster or whitewash, so that the wall looks solid and strong (v. 10) (Greenberg 1983, p. 244; Rochester 2012, p. 193). The problem is that the wall is completely inadequate for providing 
shelter from the upcoming storm. It would be utterly destroyed and whoever was relying on it for protection would be in a worse position than if they had known they were unprotected (vv. 11-15). The prophets should have known this and should have warned the people ${ }^{3}$ rather than encouraging them to waste precious time. The metaphorical "wall" might refer to the belief that Jerusalem was unassailable, to the people's trust in their own righteousness (Bowen 2010), or to hopes based on military alliances with Egypt. However, neither traditional beliefs taken out of context nor powerful allies can provide effective shelter from the attack that is about to come down on Judah.

A true prophet's job in this situation is not mitigating the harsh reality, or hiding it behind efficient double-talk and agreeable words, but to speak the truth, both with regard to Judah's wrongdoings and regarding the upcoming disaster (Sedlmeier 2002, p. 184). Words that are like smearing whitewash on a precarious wall are inadequate, illusory and deceptive. To borrow yet another phrase from Arendt, it is "speech that does not disclose what is but sweeps it under the carpet" (Arendt 1973, p. 8) and therefore it has nothing in common with hope.

\subsection{Hope vs. History (Ezek 20:1-44)}

Over against any "unfounded optimism" (Greenberg 1983, p. 238), the first 24 chapters of the book of Ezekiel are at pains to demonstrate that there is nothing in the history, or story, of Israel that warrants hope for avoiding the disaster. Employing a retributive theology that sits uneasy with (post)modern minds, ${ }^{4}$ Ezekiel points out again and again his people's incorrigible persistence in religious and moral transgressions, which according to him inevitably will lead it into severe divine judgement. Three extensive narratives, in Ezek 16; 20; 23, re-tell the story of Judah in a new light—or rather, in all its darkness. Ezek 16 and 23 use extended metaphors, likening Jerusalem respectively to a foundling girl (16) and to one of two sisters (23). Ezek 20:1-44 narrates the history of the chosen people more directly, referring to the Exodus and wilderness tradition, but it does so with an extremely negative view of the relationship between YHWH and Israel (Zimmerli 1982, p. 112). The Exodus tradition and central aspects of Israel's religious identity are evoked only to be taken ad absurdum (Sedlmeier 2002, pp. 264-65). YHWH chose Israel, "making myself known to them in the land of Egypt" (v. 5) and swore an oath to lead them to the Promised Land (v. 6). So far, the standard narratives in the books of Exodus and Hosea concur. However, Ezekiel's version of the Exodus continues, the Israelites did not listen to the promise; they refused to relinquish the worship of Egyptian gods (v. 8) and did not at any time obey YHWH's "ordinances, by whose observance everyone shall live" (v. 11). In Ezek 20, the relationship between YHWH and Israel is, from the outset, one big conflict between insubordinate humans on the one side and an increasingly exasperated deity on the other. ${ }^{5}$ Seeing his gifts of freedom and life-giving laws refused, three times-in Egypt (v. 8) and two consecutive generations in the wilderness (vv. 13,21)-YHWH would have wanted to destroy the rebellious nation he had chosen but this would have dishonoured his name (Wong 2003, pp. 217-18) since he had bound himself by oath to them. So YHWH sets them up for failure instead, giving them "statutes that were not good and ordinances by which they could not live" (v. 25), presumably so that they would destroy themselves eventually (Joyce 2009, p. 151, but see Friebel 2005). The entire story moves ominously and inexorably towards what is bound to be a bad ending or at the very least a terrifying showdown with their frustrated and furious God. Surely Ezekiel cannot be accused of optimism. His history reviews leave no room for any notion of "good old times", for anything to be proud of, or for any reason why God should not finally and once and for all destroy this troublesome people. "The idea that the people

3 This connects with the watchman theme in Ezek 3 and 33 (on which see Joyce 2009, pp. 21-22). Ezek 13:5 also suggests that the prophets should have interceded on behalf of the people before YHWH (see Rochester 2012, p. 185).

4 Tiemeyer (2010) has articulated this unease in a succinct and efficient manner, exploring a variety of ways to deal with this theologically.

5 While a similarly negative narrative is presented in Ps 78 and Ps 106, it might be argued that the situation is exacerbated in Ezekiel by the lack of any reference to divine compassion (as in Ps 106:45) or human repentance (as in Ps 78:34). 
were capable of understanding their moral failings and transforming themselves simply could not bear the weight of what Ezekiel saw as the history of failure and present of exile and destruction" (Lapsley 2000, p. 106).

And yet, paradoxically, Ezekiel's dark narratives contribute more to illuminating his "dark times" than the apparently bright and hopeful slogans of his competitors. Ezek 20 summarises in a succinct historical narrative how YHWH chose Israel and how this choice brought YHWH nothing but disappointment. Thus the chapter assumes responsibility and goes to the heart of what Ezekiel perceives to be the main problem that led to the crisis. Therefore, Ezekiel's words, metaphorical and hyperbolic as they are, contribute to uncovering, not to covering up; to revealing areas of concerns, not to whitewashing them. They are the opposite of "sweeping under the carpet," though in a crass way that is hardly bearable (not only for moderns but presumably even more so for his contemporaries). Quite apart from the question of factual accuracy, Ezek 20 offers a coherent narrative that reappropriates familiar elements from tradition to make sense of the exile, portraying it as a long-overdue justified punishment and even as a better lot than deserved. ${ }^{6}$ In the final form of the book, both chapters 16 and 20 have received somewhat more hopeful endings $(16: 60-63 ; 20: 40-44)$ to alleviate the weight of the judgement; and the motif of sparing Israel "for the sake of my name" present in 20:9, 14, 22 is taken up again in 36:21-22, there inaugurating an oracle of a hopeful new beginning (Joyce 2009, pp. 149-50) in place of the repetition of the "same old" transgressions.

\subsection{Hope vs. Despair (Ezek 37:1-14)}

As portrayed within the book, the prophet Ezekiel had to live through the very disaster he announced, experiencing deportation, loss and trauma first-hand. As a survivor among survivors, and in an environment of increasing hopelessness, Ezekiel the pessimist was forced eventually to address the question of whether there was a light at the end of the dark: the question of hope.

And so, chapters 34-48 contain a series of what exegetes call "oracles of salvation": texts of hope. It is important to notice that all texts of hope in Ezekiel are either directly connected to an announcement of judgement (often added to it almost like an afterthought: 11:14-21; 16:60-63; 20:40-44), or explicitly look back to judgement (34:2-6, 27-28; 36:16-19; 37:1-2; 43:8). Hope for Ezekiel is never about avoiding the catastrophe; it is something that emerges from the ruins in its wake. It is therefore not optimism but more akin to fundamental hope, which "acknowledges the realities of failure and defeat, but refuses to capitulate in the face of them" (Eagleton 2017, p. 65). " As mentioned above, the term "hope" does not appear in these texts, and neither do words such as "love," "consolation" or "forgiveness" (Schwartz 2000, p. 53). However, as pointed out by Block, the absence of specific vocabulary does not necessarily allow us to infer the absence of the concept as such (Block 2014b, pp. 49-50). Like most prophetic books, Ezekiel makes use of "utopian images" (Ben Zvi 2006) in the depiction of this future hope. In order to appreciate Ezekiel's hope it is therefore more helpful to focus on the images employed.

In the context of this article, particular attention shall be given to the probably most powerful text of hope in Ezekiel (if not in the entire Hebrew Bible): is 37:1-14, the well-known vision of the dry bones. Four brief observations on this remarkable text are noteworthy.

Firstly, the conceptual starting point of the vision appears quite late in the text unit. Verse 11 quotes a saying of the exilic community, a statement of hopelessness: "Our bones are dried up, and our

6 The pessimistic outlook and the language of divine wrath in Ezek 20 (e.g. "pour out my wrath" vv. 8, 13, 21, 33, 34; "spend my anger against them" vv. 8,21 ) has led to the interpretation that even the return to the land will be "not a reprieve but rather part of their sentence" (Schwartz 2000, p. 56). However, it seems necessary to note with Block that the fury of Ezekiel's God is driven by passionate jealousy (Block 2014b, p. 63) and "balanced by grace" (Block 2014b, p. 72).

7 Unsurprisingly, historical-critical scholars debated whether this remarkable shift within the book of Ezekiel is authentic, i.e., whether it goes back to the prophetic figure at its origin, or whether the texts of hope were added later in the course of redactional activity (Joyce 2009, pp. 11-12 provides a brief summary). There are good reasons to assume that the shift from announcing doom to announcing deliverance is an authentic feature already of the ministry of the prophet we call Ezekiel. This was likely accentuated in the redactional composition of the book. 
hope is lost; we are cut off completely." After the news of the fall of Jerusalem had reached the exiles in Babylonia (33:21), no one could say "All is well" any more (cf. 13:10). The unthinkable had happened and nothing, not God and not the Egyptian army, had prevented it. Humiliated, displaced, and suffering "from an intense condition of theological shock" (Block 2014a), the exiles now had lost hope. The metaphor of "dry bones" in their statement is taken literally and developed in the preceding vision (Greenberg 1997, p. 744) where the prophet is taken to a valley "full of bones [ . . ] There were very many lying in the valley, and they were very dry" (vv. 1-2). The lament of the exiles, portraying themselves as dead even though physically still alive, is thus taken very seriously. Death is a blatant reality in this vision; there is no attempt of whitewashing or softening it. The question that God asks in v. 3 refers to the real-life exiles as much as to the visionary bones; it is provocative and could be read as bordering on the cynical: "Can these bones live?"

This leads us to the second observation: the bones do come to life in this vision. ${ }^{8}$ In his discussion of utopias in prophetic books, Ben Zvi (2006, p. 64) observes that, in contrast to other literature, "prophetic texts must construe utopia as something certain to be attained". Hope essentially requires possibility (Eagleton 2017, pp. 48-49); thus in order to spark hope over against the experience of physical and metaphorical death, the text needs to demonstrate that such new life is indeed possible: that death, real as it may be-including the "death" of the Davidic monarchy, Judean political autonomy, the temple cult, and life as people knew it-does not have the last word. For God can give new life even to dry and scattered bones. To make this rather extraordinary statement more plausible, it is graphically and in detail described in a vision, instead of simply promised (Fox 1980; Hiebel 2015a, p. 276). Moreover, the vision alludes to the creation narratives in Genesis and thus to the life-giving power of the Creator God. Just as God's creative word ordered the chaos in the beginning (Genesis 1), now God's word re-creates and re-unites what is scattered and lifeless. And just as YHWH God formed the first human being from the dry soil and then breathed life into him (Gen 2:7), Lord YHWH causes bodies to form from the dry bones and then has "the breath" (hrwh) — the principle of life personified-breathe life into these bodies (Ezek 37:7-10). ${ }^{9}$

Thirdly, while it is obviously God who performs the miracle, the prophet's contribution is unusually critical when compared to the other visions in the book of Ezekiel. Normally, in the vision accounts, the prophet's role is that of a silent witness $(8-10 ; 40-48)$ or that of the recipient of a message (1-3) (Hiebel 2015a, pp. 269-70). Here, although it is emphasised that Ezekiel only does as he is commanded (vv. 7, 10), it is his prophesying to the bones that initiates the process of reanimation. It is his calling on "the breath" (hrwh) that enables life to enter into the reassembled corpses. It is his docility to God's word-which contrasts with the disobedience of his people as portrayed in Ezek 20 and elsewhere in Ezekiel - that acts as a catalyst to the miracle of new life. The prophet's contribution is accentuated by the general theocentricity of the book of Ezekiel, which tends to focus mainly on YHWH and YHWH's actions at the expense of all other characters (Joyce 2009, pp. 27-31).

Finally, v. 11 explicitly equates the bones to the "whole house of Israel." The ensuing vv. 12-14 promise them an analogous treatment to that which the bones have just received in the vision. The detailed promise to the bones in vv. 5-6 contained everything necessary to restore physical life to them: sinews, flesh, skin, and breath ( $r w h)$, which is mentioned twice and both times followed immediately by "and you shall live." The promise then culminates in the so-called recognition formula, "and you/they will know that I am YHWH" (v. 6), which recurs, with minor variations, around 70 times in Ezek 1-39 (Zimmerli 1982, 1979, pp. 37-40). Analogously, the promise to the exiles (vv. 12-14) contains everything necessary for their regaining life in a deeper sense and for their restoration as a people: being led out of their "graves", out of exile, and brought back to their own land (v. 12, 13).

8 There is nothing in Ezek 37:1-14 that suggests this revivification, or the ensuing knowledge of YHWH, happen against the bones'/exiles' will (as proposed by Schwartz 2000, p. 59).

9 See also Ps 104:29-30. For more allusions to Genesis 2, see Kutsko (2000, pp. 133-34) who connects the creation motifs to polemics against idols (Kutsko 2000, p. 142). 
However, even ending the exile would not be sufficient to restore them to life in the full sense of the word. Once more, rwh is promised (v. 14), but in this context it is "not the ordinary, natural life-breath common to all living things; it is the spirit of God himself" (Block 1989, p. 38). This is again followed by the same words, now resonating with a deeper meaning: "You will live [ ... ] and you will know that I [am] YHWH" (v. 14; literal translation). As "the breath" (hrwh) breathes life into the bodies in v. 9, in v. 14 the spirit of YHWH enters God's people, renewing their previously problematic relationship with their God (Schüngel-Straumann 1996, pp. 211-12). By playing on the different meanings of the word rwh, the narrative intensifies the parallel between the restoration of physical life and the restoration of life in the wider sense of hope, courage, and renewal.

More than any other text, 37:1-14 speaks of a hope that is to some extent beyond reason, though not unreasonable in the context of faith. Couched in the literary form of a vision, it depicts the utopian transformation of reality from as it is (death) to as it should be according to the will of God (life). Significantly, this transformation arises only after "death", i.e., the just consequence of rebellion against God, has fully occurred. It is therefore not hope in avoiding the disaster, it is not optimism; it is a kind of hope that paradoxically begins where one would expect hope to cease. Importantly, the vision and all it announces is dependent on YHWH only, with no pre-conditions to be met. ${ }^{10}$ It is further significant to note that the "resurrection" of the bones is metaphorical language, which expresses the power of God the Creator in this world, not an eschatological idea of resurrection to eternal life. ${ }^{11}$ Ezek 37 expects God to act in the near future and seeks to influence its readers in their present state of hopelessness (Fox 1980).

\subsection{Hope for Times without Darkness (Ezek 34-48)}

So far we have seen that, living through a time of political, theological and social collapse, Ezekiel — the writings in the book that bears his name-resist both naïve optimism and paralysing despair. Ezek 37:1-14 recalls the power of God as creator, affirming the possibility of new life (i.e., return and renewal) on the basis of this power. Indeed, the book tends so to emphasise YHWH's agency and sovereignty that all other characters, including the prophet and the Babylonian king, appear as little more than "marionettes" (Tiemeyer 2011). This theocentricity is a dominant feature in Ezekiel.

At the same time, it is precisely the portrayal of God that probably is also the most problematic feature in Ezekiel. Ezekiel's God is depicted as powerful, holy, and just, but at the same time as vindictive and violent, lacking the kind and merciful traits common to other biblical books. His concern with honour and cultic purity is foreign to contemporary Western cultures. The oracles of judgement are chillingly pitiless and even the promises of restoration lack the warmth we may find in Jeremiah or Second Isaiah (Schwartz 2000, p. 50; Mein 2001, pp. 242-44). Given the historical circumstances, this is probably because divine attributes like love and mercy were too much at odds with the prophet's environment and life experience. After all, reconciling divine love and human suffering has remained a serious challenge even throughout 2000 years of Christian theology, despite the latter's roots in the paradox of a crucified Redeemer.

Ezekiel's hope is devoid of any notion of divine compassion or pardon (Schwartz 2000, pp. 53-54); instead, it is based on the prosaic insight that it is in this powerful God's own interest to ensure a future for his wayward people because the restoration of God's name involves the restoration of Israel (Wells 2000, p. 168). ${ }^{12}$ In ancient Near Eastern world view, a national deity and its people were very closely linked to each other. Judah's disobedience dishonours their God, and thus YHWH's punitive

10 According to Ben Zvi (2006, p. 65), this is typical for prophetic utopian images.

11 However, as the most powerful metaphor possible for expressing a theologically-based hope beyond all probability, it is not surprising that this text came to be read, over the centuries, through an eschatological lens. The survey by Olley (2011) mentions an eschatological and individual interpretation already in Pseudo-Ezekiel, among the Qumran writings.

12 Even Schwartz, in proposing "Ezekiel's dim view of Israel's restoration," asserts the "indestructible character of the bonds that tie YHWH to Israel" (Schwartz 2000, p. 67). 
actions are seen as an attempt to restore his honour. However, a complete annihilation of Judah would dishonour YHWH even more severely (Wong 2003). Ezek 36:22 summarises YHWH's motivation in a fitting catchphrase: "It is not for your sake, O house of Israel, that I am about to act, but for the sake of my holy name" (cf. 36:32). The shift in Ezekiel from announcing destruction to promising deliverance never obliterates the history of human failure the prophet had perceived in his people. Accordingly, the proclamation that God will save is not due to any human merits. No oracle of salvation in Ezekiel lists any improvement of human behaviour as pre-condition or reason for divine action (Joyce 2009, pp. 26-27). Rather, the motivation is one of "divine self-interest" (Joyce 2009, p. 29): in order to vindicate God's holy name, i.e., God's honour. This does not mean that Israel will not benefit from God's action (as presumed by (Schwartz 2000)); it simply means that the restoration is entirely "an act of grace and divorced from any merit" (Block 2014b, p. 71), having as its ultimate aim divine revelation and glorification. In other words: God reveals himself as God not only by judging Israel, but even more so by restoring the relationship out of his own initiative. This is why the ultimate promise to the dead bones and to the exiles is not "and you shall live" $(37: 5,6,14)$ but precisely "and you shall know that I am YHWH" $(37: 6,13,14)$ (Hiebel 2015b, p. 253).

It can be concluded that Ezekiel is conducting a deep analysis of the reasons that led his people into the crisis in which they find themselves. To be sure, his analysis is theological and operating with variables of a transcendent nature. In ascertaining the deep reasons for the disaster he does not remain on the level of foreign politics and Empire but identifies a long-standing and habitual noncompliance to divine rules with regards to ethics and cult. As a consequence, Judah's own God has brought about the disaster. While this kind of analysis may appear unhelpful and even cynical, it is consonant with its cultural and religious environment. More importantly, by identifying Judah's God as the driving force of the disaster, because of human disobedience, Ezekiel also found a strong foundation for hope. For if there still was a connection between YHWH and Judah, and if YHWH's power was unabated, it was reasonable to hope YHWH would eventually restore the nation's fortune, as long as a solution to the problem of human disobedience could be found.

Ezekiel's imagination of the result of such saving divine intervention is conveyed in striking images that use traditional themes in a creative way and paint an idealised picture of the future, including a lasting solution to disobedience. These images envision a future where everything that was lost-king, temple, dignity and land - is not only restored and renewed but better than it ever was. Instead of the corrupt and self-serving "shepherds" of the past (34:2-4), God will now look after his "flock" in person (34:10-16). The Davidic line will be restored but only as "my servant" who "shall feed them" (34:23). Return to the land is of course a frequent theme (e.g., 11:17; 20:42; 34:13; 36:24; $37: 12,14,21)$, and the land itself is also going to be restored with regard to its fertility (e.g., 34:27; 36:29-30; 47:1-12) as well as in terms of the reconstruction of cities (e.g., 36:8-11, 33-35). The old defiled temple that was destroyed (8-11) will be replaced by a new sanctuary where God will be present again among his people forever (37:27-28; 40-48). In contrast to 13:10, 16 (and 7:25) stating that "nothing was well" or "there was no peace", and over against the old covenant that was broken (16:59; 17:18-19), now God is offering a "covenant of peace" $(34: 25 ; 37: 26)$, which will be an "everlasting covenant" (37:26; see 16:60) because it can no longer be broken by human non-cooperation. ${ }^{13}$ It will be established by God in a unilateral action, and God will solve the problem of human disobedience through transformation and inner renewal of God's people (Lapsley 2000) who will receive God's spirit $\left(37: 14 ; 36: 27^{14}\right.$; see $\left.11: 19\right)$ and will undergo a change of heart $(11: 19 ; 36: 26)$, thus being enabled to "follow

13 Andrew Mein (2001, p. 249) observes that "Ezekiel appears to be drawing on a range of covenantal traditions, but emphasising those that stress the unconditional and permanent nature of Israel's restored relationship with YHWH". Bowen (2010) critically remarks that any attempt to eradicating human obedience is ultimately unrealistic.

14 Ezek 36:23b $3-38$ appears to be a very late text, as it is lacking in the oldest Greek Ezekiel manuscript (see Lust 1981; Crane 2008; Lilly 2012). It constitutes a summary of Ezekiel's theology, taking up themes and phrases from various parts of the book. 
my statutes and be careful to observe my ordinances. Then you shall live in the land that I gave to your ancestors; and you shall be my people, and I will be your God" (36:27-28; see 11:19-20). Indeed, human compliance is assured so unilaterally by divine initiative that it appears almost "accomplished by force" (Schwartz 2000, p. 47), especially when taking into account the absence of "love" and "compassion" vocabulary throughout the book, including in chapters $34-48 .^{15}$ The point seems to be that Ezekiel builds the foundations on which he rests his hope as entirely separated from the sphere of human collaboration or non-collaboration (Hiebel 2015a, p. 293).

Ezekiel's combination of moral pessimism (Ezek 20) and theocentric hope (Ezek 34-48) thus leads to the development of a precursory notion of sola gratia, in the sense that salvation-understood as concrete rescue in this lifetime, not in an eschatological sense-will not depend on human merits but solely on God (Zimmerli 1963, p. 147; Joyce 2009, p. 27; Block 2014b, p. 71). This theocentricity is also intrinsically connected to the emerging of theoretical monotheism that allows to conceive of the One God as untouched by the collapse of the nation's institutions (Sanders 1997, pp. 44-45), which will be articulated more explicitly later in Second Isaiah (e.g., Isa 45). Hope is therefore grounded in the one entity that cannot be subject to the otherwise all-engulfing crisis.

In this sense, Ezekiel's hope is utopian. It is not so much a social critique because in its historical context, the exiles had little control over their society (Mein 2001) but it does "depict the world 'as it should be'" (Schweitzer 2006, p. 19), creating - in outline-a world which is fundamentally different from the present and the past world of the author, even though the texts employ traditional themes and re-enact the promises of old. Against the backdrop of past failings and present defeat and oppression, Ezekiel 34-48 posits that all this "must and will be replaced by a new world [ ... ] in which the perceived wrongs of the status quo will be fully redressed" (Ben Zvi 2006, p. 62), indeed in which the very root cause of the "wrongs" - human disobedience to God-is entirely eliminated. Hope in Ezekiel is, therefore, not a matter of "restoration" in the literal sense of returning to the past state of affairs-despite drawing on the old traditions and institutions-but it points towards the creation of a new reality that does not exist and has never existed in the author's experience but that can be brought about by divine intervention. It should moreover be noted that all these promises are addressed to the community and are not intended in an individualistic sense (Mein 2001, p. 220). Hope is collective, like the disaster had been collective. And despite the utopian character of Ezekiel's promises of salvation, these also contain a strong element of immediacy and are directed to the present of the exilic community (Sedlmeier 2002, pp. 70-71) as well as of later readers of the book (Konkel 2015).

\section{An Open Conversation: What Ezekiel Can (And Can't) Tell Us Today}

We do not know to what extent the book of Ezekiel succeeded in instilling hope in its historical audience of deportees. The very fact that the book was copied and edited and handed down through the centuries would suggest that it had a significant effect on some people at least. What we do know is that, historically speaking, many of the promises contained in the book remained essentially unfulfilled, especially for its original audience. Even though some Judeans were able to return to their homeland sometime after the Persian conquest of the Babylonian Empire in 539 BCE, Ezekiel and the first generation of deportees most likely would have had died by then. And even though Jerusalem and the temple were rebuilt, life in the Persian province of Yehud was certainly not the terrestrial paradise as described in the prophecies (Albertz 2003, p. 132; Grabbe 2015).

Still, Ezekiel and his followers contributed a great deal to the important theological developments which would be the fruit of the Babylonian Exile and become part of the common heritage of both

15 However, and contrary to Schwartz's interpretation, Ezekiel does contain a hopeful view of the future, not one of perpetuated punishment. Schwartz's assertion that the exiles will be returned to the land against their will (Schwartz 2000, p. 59) has no real foundation in the text. As for shame, which Schwartz views entirely negatively, Lapsley has pointed out that "[t]he capacity to remember their actions as loathsome [ ... ] is the equivalent of a new moral self, capable of making accurate moral assessments" (Lapsley 2000, p. 141), i.e., a positive development. 
Judaism and Christianity. Judean identity did not get lost in the crisis but emerged altered and stronger. The Babylonian Exile shaped the future of YHWH religion in a unique way. The Bible, both the Old and the New Testament as we know them, would not exist or look very different without the Babylonian Exile (Sanders 1997). Judaism and Christianity would not exist, or look very different (Albertz 2003, pp. 435-45).

Without wishing to be comprehensive, the following will point out some aspects of the theological contribution of the book of Ezekiel that are relevant to the topic of hope in dark times, while at the same time acknowledging that much of the logic of Ezekiel's theocentric hope is bound to remain ultimately foreign to modern thinking. Besides the differences in cultural and historical setting (e.g., regarding the importance of honour), there are aspects to this biblical prophetic book that will necessarily appear as problematic from a present-day perspective and therefore cannot simply be transferred to the present (Lapsley 2000, p. 189). Dialogue is possible, however. Ezekiel's was a prophetic voice in the midst of very dark times, and even though quite different from the narratives Hannah Arendt collects in her Men in Dark Times, it may be safe to say that his voice too shed "some illumination" in his time (Arendt 1973, p. 9). Significantly, Joyce speaks of "a glimmer of theological light" offered even by "Ezekiel's theological message of judgement" (Joyce 2009, p. 18) and even more so, we may surmise, by his subsequent message of hope. If it is at all possible to learn from history, learning from the greatest successfully overcome crisis in Old Testament times may well be a good place to start. With this awareness, the following paragraphs simply intend to sketch some pathways of thought that may consent us to open up a dialogue between the book of Ezekiel and contemporary situations.

First and foremost, having its roots at the very beginning of the exile, Ezekiel's writings provide a coherent narrative of the traumatic events and their underlying causes. Inhabitants of the 21st century will object to this narrative's categorical attribution of the responsibility for the catastrophe to the people who suffered it, which sounds not only very harsh, but much like blaming the victims. There will also be reservations against positing a direct divine intervention in the unfolding of historical events. Nevertheless, quite apart from questioning the content of the narrative Ezekiel provides, it needs to be acknowledged that the very fact of providing a narrative that makes sense within a specific cultural context is a priceless contribution as such. Humans are essentially meaning-making creatures, and enabling traumatic events to be integrated into the framework of collective memory gives meaning to suffering and makes it easier to cope. In fact, theorists such as Cathy Caruth would argue that trauma consists precisely in an event that cannot be integrated in any pre-existing framework. There seems to be a recognition of the role of narrative in dealing with a traumatic past in Arendt (1973, p. 29). In Ezekiel's case, providing a narrative allowed maintaining Judean identity (as opposed to assimilation into Babylonian culture) by offering an interpretation of the events based on elements of Judean tradition (Delorme 2019). It thus paved the way for a continuing YHWH religion and, therefore, Second Temple Judaism (Joyce 2009, pp. 17-18). Undoubtedly, a present-day narrative will look very different from Ezekiel's, but the question remains essentially the same: what are the elements of our traditions, religious and secular, that will help shape a narrative of the early 21st century that can provide coherence and meaning in the midst of fragmentation and confusing complexity?

Of course, not just any narrative will do. Ezek 13:1-16 emphasises that words which, as it were, paint over the cracks in walls that are already falling apart are not trustworthy but indeed dangerous. Hope requires a reliable and reasonable foundation, and this in turn requires an honest search for truth, the courage to go to the heart of problems, and the resolution to address the failures of the past and of the present. Narratives that promote wishful thinking and a false sense of security have no room in a prophetic book.

A second characteristic of the narrative provided by the book of Ezekiel is that it took people's life experience seriously and at the same time transcended it. This touches on another challenging aspect of the book: Ezekiel is replete with depictions of violence; and it is problematic that the texts largely seem to justify this violence by interpreting it as deserved divine punishment. Yet the violence and turmoil in the text reflect the actual violence and trauma experienced by both author and audience and, 
despite its harshness, the narrative is an attempt to make sense of what otherwise would have been meaningless chaos (Joyce 2009, p. 19). ${ }^{16}$ Ezekiel was relevant because his audience could recognise their reality and their questions in his message. The brutality of their experience was never denied or covered up; at the same time, however, not the experience of loss and defeat was given the last word, but hope. Again, present-day responses to crisis will be phrased differently, but Ezekiel, alongside other biblical traditions, provides an excellent example of taking unpleasant reality seriously while at the same time not letting it determine one's entire horizon.

This is made possible by a third feature of Ezekiel: his theocentricity, which provided an anchor in the upheaval of the events. Religious traditions hold a great potential to provide hope in seemingly hopeless circumstances, as the overcoming of a crisis is not seen as depending exclusively on the human response to it, be it personal or collective, though that response remains as crucial as Ezekiel's prophesying to the bones. Therefore, a goal unattainable through human efforts may be seen as surely attainable through divine intervention. Faith and hope are closely related (Eagleton 2017, pp. 39-42). The tension between appreciating the direness of the situation and yet finding hope that transcends that very situation is an essential trait of hope in dark times. This is a challenge even for people of faith; a secular society that prefers to reason without reference to a transcendent Supreme Being will need to find altogether new anchors and new grounds for such hope.

Finally, the book of Ezekiel is a reminder that hope, in biblical terms, is about the big picture. This recognition is crucial. For from a safe historical distance we are able to see that the prophet was right: the Babylonian Exile was not the end of Judean identity. It was, paradoxically, a catalyst to an extremely fruitful theological development, which was critical for the composition of the Bible and laid the foundations of Second-Temple Judaism and, later, Christianity. However, this observation is possible only in hindsight. As noted above, Ezekiel's generation only experienced the loss, suffering, and trauma of a displaced people (Smith-Christopher 2002), and most probably died in the foreign land. Nonetheless, their hope and their courage to persist in hoping would have been vital to any subsequent positive developments. In Zimmerli's words, "this salvation was already inbreaking reality in the prophetic word itself" (Zimmerli 1982, p. 96). This self-fulfilling tendency of hope, which assists or enables the fulfilment of that which is hoped for, is not to be underestimated and is, indeed, encouraging.

While it is obvious that the message and theology of Ezekiel cannot be directly transferred into our times, this article has aimed to demonstrate that theological reflection on Ezekiel can nonetheless make a contribution to the reflection on our own troubled times.

Funding: The Article Processing Charges were funded by institutions through Knowledge Unlatched.

Acknowledgments: Unless otherwise stated, Scripture quotations are from the New Revised Standard Version Bible, copyright(C) 1989 National Council of the Churches of Christ in the United States of America. Used by permission. All rights reserved worldwide.

Conflicts of Interest: The author declares no conflict of interest.

\section{References}

Albertz, Rainer. 2003. Israel in Exile: The History and Literature of the Sixth Century B.C.E. Translated by David Green. Studies in Biblical Literature 3. Atlanta: SBL.

Arendt, Hannah. 1973. Men in Dark Times. Harmondsworth: Penguin Books.

16 It is important to keep in mind that the perspective is that of the victims. The Babylonian Exile as such shows that both Judaism and Christianity have their roots in the history of the losers and the powerless, not the conquerors and the powerful. This theme runs in a variety of threads throughout the entire Bible and should serve as a reminder that any kind of triumphalism should never sit easy with Christianity. Smith-Christopher (2002) makes this point quite clearly. 
Ben Zvi, Ehud. 2006. Utopias, Multiple Utopias, and Why Utopias at all? The Social Roles of Utopian Visions in Prophetic Books within their Historical Context. In Utopia and Dystopia in Prophetic Literature. Edited by Ehud Ben Zvi. Göttingen: Vandenhoeck \& Ruprecht, pp. 55-85.

Berkowitz, Roger. 2010. Introduction: Thinking in Dark Times. In Thinking in Dark Times: Hannah Arendt on Ethics and Politics. Edited by Roger Berkowitz, Jeffrey Katz and Thomas Keenan. New York: Fordham University Press, pp. 3-14. [CrossRef]

Block, Daniel I. 1989. The Prophet of the Spirit: The Use of rwh in the Book of Ezekiel. Journal of the Evangelical Theological Society 32: 27-49.

Block, Daniel I. 2014a. The Theology of Ezekiel. In By the River Chebar: Historical, Literary, and Theological Studies in the Book of Ezekiel. Cambridge: James Clarke, pp. 25-43.

Block, Daniel I. 2014b. The God Ezekiel Wants Us to Meet. In By the River Chebar: Historical, Literary, and Theological Studies in the Book of Ezekiel. Cambridge: James Clarke, pp. 44-72.

Bowen, Nancy R. 2010. Ezekiel. Abingdon Old Testament Commentaries. Nashville: Abingdon Press.

Cornell, Drucilla. 2010. Thinking Big in Dark Times. In Thinking in Dark Times: Hannah Arendt on Ethics and Politics. Edited by Roger Berkowitz, Jeffrey Katz and Thomas Keenan. New York: Fordham University Press, pp. 221-27. [CrossRef]

Crane, Ashley S. 2008. Israel's Restoration: A Textual-Comparative Exploration of Ezekiel 36-39. Supplements to Vetus Testamentum 122. Leiden: Brill.

Delorme, Jean-Philippe. 2019. בית ישראל in Ezekiel: Identity Construction and the Exilic Period. Journal of Biblical Literature 138: 121-41. [CrossRef]

Eagleton, Terry. 2017. Hope without Optimism. New Haven: Yale University Press.

Faust, Avraham. 2012. Judah in the Neo-Babylonian Period: The Archaeology of Desolation. Society of Biblical Literature Archaeology and Biblical Studies 18. Atlanta: SBL.

Fox, Michael V. 1980. The Rhetoric of Ezekiel's Vision of the Valley of the Bones. Hebrew Union College Annual 51: 1-15.

Friebel, Kelvin G. 2005. The Decrees of Yahweh that are 'Not Good': Ezekiel 20:25-26. In Seeking Out the Wisdom of the Ancients: Essays Offered to Honor Michael V. Fox on the Occasion of His Sixty-Fifth Birthday. Edited by Ronald L. Troxel, Kelvin G. Friebel and Dennis Robert Magary. Winona Lake: Eisenbrauns, pp. 21-36.

Grabbe, Lester L. 2015. The Reality of the Return: The Biblical Picture Versus Historical Reconstruction. In Exile and Return: The Babylonian Context. Edited by Jonathan Stökl and Caroline Waerzeggers. Boston: De Gruyter, pp. 292-307.

Greenberg, Moshe. 1983. Ezekiel 1-20: A New Translation with Introduction and Commentary. Anchor Bible 22/1. New York: Doubleday.

Greenberg, Moshe. 1997. Ezekiel 21-37: A New Translation with Introduction and Commentary. Anchor Bible 22/2. New York: Doubleday.

Hiebel, Janina Maria. 2015a. Ezekiel's Vision Accounts as Interrelated Narratives: A Redaction-Critical and Theological Study. Beihefte zur Zeitschrift für die alttestamentliche Wissenschaft 475. Berlin: W. de Gruyter.

Hiebel, Janina Maria. 2015b. Visions of Death and Re-creation: Ezekiel 8-11, 37:1-14 and the Crisis of Identity in the Babylonian Exile and Beyond. Pacifica: Journal of the Melbourne College of Divinity 28: 243-55. [CrossRef]

Joyce, Paul M. 2009. Ezekiel: A Commentary, 2nd ed. Library of Hebrew Bible/Old Testament Studies 482. New York: T\&T Clark.

Konkel, Michael. 2015. 'Kehrt um, kehrt um!' (Ez 33,11): Die Ethik des Ezechielbuches zwischen Determinismus und Freiheit. In Mehr als Zehn Worte? Zur Bedeutung des Alten Testaments in ethischen Fragen. Edited by Christian Frevel. Freiburg: Herder, pp. 208-32.

Kutsko, John F. 2000. Between Heaven and Earth: Divine Presence and Absence in the Book of Ezekiel. Biblical and Judaic Studies from the University of California 7. Winona Lake: Eisenbrauns.

Lapsley, Jacqueline E. 2000. Can These Bones Live? The Problem of the Moral Self in the Book of Ezekiel. Beihefte zur Zeitschrift für die alttestamentliche Wissenschaft 301. Berlin: De Gruyter.

Lilly, Ingrid E. 2012. Two Books of Ezekiel: Papyrus 967 and the Masoretic Text as Variant Literary Editions. Vetus Testamentum Supplements 150. Leiden: Brill.

Luban, David. 1983. Explaining Dark Times: Hannah Arendt's Theory of Theory. Social Research 50: $215-48$.

Lust, Johan. 1981. Ezekiel 36-40 in the Oldest Greek Manuscript. Catholic Biblical Quarterly 43: 517-33. 
Mein, Andrew. 2001. Ezekiel and the Ethics of Exile. Oxford Theological Monographs. Oxford: Oxford University Press.

Olley, John W. 2011. Trajectories of Ezekiel (Part 2): Beyond the Book. Currents in Biblical Research 10: 53-80. [CrossRef]

Rochester, Kathleen M. 2012. Prophetic Ministry in Jeremiah and Ezekiel. Contributions to Biblical Exegesis and Theology 65. Leuven: Peeters.

Sanders, James A. 1997. The Exile and Canon Formation. In Exile: Old Testament, Jewish, and Christian Conceptions. Edited by James M. Scott. Leiden: Brill, pp. 37-61.

Schüngel-Straumann, Helen. 1996. Rûah und Gender-Frage am Beispiel der Visionen beim Propheten Ezechiel. In On Reading Prophetic Texts: Gender-Specific and Related Studies in Memory of Fokkelien van Dijk-Hemmes. Edited by Bob Becking and Meindert Dijkstra. Leiden: Brill, pp. 201-15.

Schwartz, Baruch J. 2000. Ezekiel's Dim View of Israel's Restoration. In The Book of Ezekiel: Theological and Anthropological Perspectives. Edited by Margaret S. Odell and John T. Strong. Atlanta: SBL, pp. $43-67$.

Schweitzer, Steven James. 2006. Utopia and Utopian Literary Theory: Some Preliminary Observations. In Utopia and Dystopia in Prophetic Literature. Edited by Ehud Ben Zvi. Göttingen: Vandenhoeck \& Ruprecht, pp. 13-26.

Sedlmeier, Franz. 2002. Das Buch Ezechiel: Kapitel 1-24. Neuer Stuttgarter Kommentar Altes Testament 21/1. Stuttgart: Katholisches Bibelwerk.

Sheridan, Greg. 2018. God is Good for You: A Defence of Christianity in Troubled Times. Sydney: Allen \& Unwin.

Smith-Christopher, Daniel L. 2002. A Biblical Theology of Exile. Overtures to Biblical Theology. Minneapolis: Fortress.

Smith, Daniel L. 1989. The Religion of the Landless: The Social Context of the Babylonian Exile. Bloomington: Meyer-Stone Books.

Tiemeyer, Lena-Sofia. 2010. To Read-Or Not to Read-Ezekiel as Christian Scripture. The Expository Times 121: 481-88. [CrossRef]

Tiemeyer, Lena-Sofia. 2011. Ezekiel: A Compromised Prophet in Reduced Circumstances. In Constructs of Prophecy in the Former and Latter Prophets and Other Texts. Edited by Lester L. Grabbe and Martti Nissinen. Atlanta: SBL, pp. 175-95.

Volf, Miroslav. 2012. God, Hope, and Human Flourishing. In Covenant and Hope: Christian and Jewish Reflections. Edited by Eugene Korn and Robert W. Jenson. Grand Rapids: Eerdmans, pp. 73-78.

Wells, Jo Bailey. 2000. God's Holy People: A Theme in Biblical Theology. Journal for the Study of the Old Testament Supplement Series 305. Sheffield: Sheffield Academic.

Wong, Ka Leung. 2003. Profanation/Sanctification and the Past, Present and Future of Israel in the Book of Ezekiel. Journal for the Study of the Old Testament 28: 210-39. [CrossRef]

Zimmerli, Walther. 1963. Das Gotteswort des Ezechiel. In Gottes Offenbarung: Gesammelte Aufsätze zum Alten Testament. Munich: C. Kaiser, pp. 133-47.

Zimmerli, Walther. 1979. Ezekiel 1: A Commentary on the Book of the Prophet Ezekiel, Chapters 1-24. Translated by Ronald E. Clements. Hermeneia: A Critical and Historical Commentary on the Bible. Philadelphia: Fortress, vol. 1.

Zimmerli, Walther. 1982. I Am Yahweh. Translated by Douglas W. Stott. Edited by Walter Brueggemann. Atlanta: John Knox.

(C) 2019 by the author. Licensee MDPI, Basel, Switzerland. This article is an open access article distributed under the terms and conditions of the Creative Commons Attribution (CC BY) license (http://creativecommons.org/licenses/by/4.0/). 